\title{
Relationship between protective maternal behavior and some reproductive variables in zebu-type cows (Bos indicus)
}

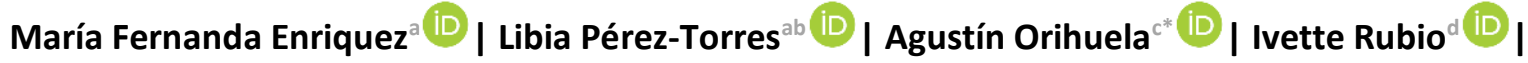 \\ Manuel Corro $^{d}$ (iD) | Carlos Salvador Galina
}

aDepartamento de Reproducción, Facultad de Medicina Veterinaria y Zootecnia, Universidad Nacional Autónoma de México, Ciudad Universitaria, 04510 México, D.F., México.

bPrograma de becas posdoctorales en la UNAM DGAPA. Facultad de Medicina Veterinaria y Zootecnia, Universidad Nacional Autónoma de México.

'Facultad de Ciencias Agropecuarias, Universidad Autónoma del Estado de Morelos, Av. Universidad 1001, Colonia Chamilpa, Cuernavaca, Morelos 62210, México. 'Centro de Enseñanza Investigación y Extensión en Ganadería Tropical, Facultad de Medicina Veterinaria y Zootecnia, Universidad Nacional Autónoma de México, Tlapacoyan, Veracruz, México.

*Corresponding author: aorihuela@uaem.mx

\begin{abstract}
To determine a possible relationship between protective maternal behavior and some reproductive variables in zebu cows, 30 cow-calf pairs were estrus synchronized at 25 days post-partum. No differences were observed in the number of cows displaying estrus or ovulating between those cows reacting to more calves with higher intensity, and the rest of the herd $(P>0.05)$. However, significant negative correlations were found between cows reacting to more calves and the presence of follicles $(-0.39 ; P=0.03)$, and cows displaying a more intense reaction toward their calf and estrous display ($0.46 ; P=0.01)$. Current results suggest that protective maternal components might affect some reproductive variables.
\end{abstract}

Keywords beef cattle, estrus, mother-calf association, ovarian activity, postpartum activity, temperament

\section{Introduction}

Maternal protective behavior could help to increase the survival of their young, particularly in beef cows raised under extensive conditions where predators can represent a danger for the calves (Flörcke et al 2012). This behavior is associated with temperament (Orihuela et al 2020) and it has been seen that the temperament of the cows, influences cattle reproductive efficiency. For example, cows with calm temperaments have a significantly higher pregnancy rate in comparison with nervous cows (Cooke et al 2009; Kasimanickam et al 2014; Cooke et al 2017). Furthermore, Cziszter et al (2016) suggested that selection for calmer temperaments will translate into increased production and shorter calving intervals.

An improvement in the reproductive efficiency of the cow, coupled with a greater probability of survival of their young, would mean better profits for the producer. However, the association between maternal protective behavior and reproductive aspects in Bos indicus cattle has not been studied. Thus, the objective of the present experiment was to determine a possible relationship between protective maternal behavior and some reproductive variables in zebutype cattle.

\section{Materials and Methods}

The study was undertaken at the Centro de Enseñanza, Investigación y Extensión en Ganadería Tropical, belonging to the Facultad de Medicina Veterinaria de la
Universidad Nacional Autónoma de México, located in Veracruz, Mexico, at $20^{\circ} 4^{\prime} \mathrm{N}$ and $97^{\circ} 3^{\prime} \mathrm{W}$. The climate is hot and humid, without a defined dry season. The average yearly rainfall is $1840 \mathrm{~mm}$, and the average temperature ranges between 14 and $35^{\circ} \mathrm{C}$.

The methods were approved by the Ethical Committee for Experimentation in Animals of the Faculty of Veterinary Medicine, the University of Mexico following The Code of Ethics of the World Medical Association (Declaration of Helsinki).

\subsection{Animals and management}

Thirty Bos indicus cow-calf pairs raised under extensive conditions were used. All cows were multiparous between 4 - 6 years old with the body condition of $4.0 \pm 0.08$, on a 1 to 9 scale. All animals were kept in a single herd on a Cynodon pasture, under a continuous suckling system, with negligible previous contact with humans before parturition. Cows and calves were identified with large numbers painted with hair dyes on their flanks, to identify them at a distance.

\subsection{Maternal Protectiveness test}

A maternal protection test (Haskell et al 2014; PérezTorres et al 2014) was carried out for all cows at $25 \mathrm{dpp}$. In general, calves could walk individually and freely for $30 \mathrm{~s}$ in front of the continuous pen where all cows were hold. A 3 min period was allowed between each test to favor certain independence within the experimental animals. The behavioral response of the cow towards each calf was scored 
from 1 to 5 by the same person. A score of 1 , meant that the cow stands very quietly or rather shows indifference; $2=$ the cow stands quietly and observes the calf occasionally; $3=$ the cow displays vigorous tail swishing, occasionally pawing the ground; 4 = the cow bellows loudly and moves restless from side to side of the pen; 5 = the cow is aggressive and tries to get through the fence, and the handler only feels safe because of the fence separation.

Cows were classified as protective $(P)$ when they reacted towards $\geq 3$ calves: including or not her calf in intensities $\geq 3$; whilst non-protective cows (NP), did not react or reacted to $\leq 2$ calves with a reaction intensity $\leq 2$.

\subsection{Reproductive variables}

All cows were estrus synchronized at 16 days postpartum (dpp) using an intravaginal progesterone releasing device (Eazy-breed CIDR; Pfizer, Mexico City Mexico) which remained in situ for 9 days. After CIDR withdrawal, the number of follicles was determined every day for $4 \mathrm{~d}$ using a real-time B-mode linear array ultrasound scanner with a 7.5 $\mathrm{MHz}$ rectal probe (Aloka SSD-500, Tokyo, Japan).

Ovulation was determined by the presence of a corpus luteum (CL) determined by ultrasound (same as above), and serum progesterone (P4) concentration $>1 \mathrm{ng} / \mathrm{ml}$ at $35 \pm 1$ dpp. Blood samples were obtained from the coccygeal vessels, using Vacutainer ${ }^{\circledR}$ tubes without anticoagulant and centrifuged at $3000 \mathrm{rpm}$ for $30 \mathrm{~min}$. Serum was stored in 1.6 $\mathrm{ml}$ Eppendorf vials at $-20^{\circ} \mathrm{C}$.

Progesterone concentrations were determined using a commercial solid-phase RIA kit (Progesterone, Coat-ACount, Diagnostic Products, Los Angeles, CA, USA; batch TGC2 0417) validated for bovine. The intra-assay coefficient of variation was $6.9 \%$.

Estrous detection was conducted for $96 \mathrm{~h}$ after CIDR withdrawal. From 07:00 to 19:00 h by direct observation and at night with the help of ESTROTECT patches (Rockway, Spring Valley, WI, USA) that were checked each morning 07:00 h.

\subsection{Data analysis}

Comparisons between $\mathrm{P}$ and NP cows were made by The U-Mann Whitney test for the intensity of the reaction, and the number of the calves towards each cow reacted; The Chi-square test for the proportion of animals displaying estrus, ovulating and with follicular presence, and the TStudent for the number of follicles, the onset of estrus ( $h$ ) and progesterone concentration. Besides, to establish the degree of association between maternal behavior and reproductive characteristics, a point-biserial correlation was used for dichotomous variables, while the Spearman correlation test for ordinal and continuous variables.

\section{Results}

Twelve (40\%) of the 30 cows did not show maternal protective behavior in any case. Of the remainder, $8(27 \%)$ did so exclusively in response to their calf, while 10 (33\%) reacted to their calf and calves from other cows as well. Seventeen (57\%) cows were classified as $P$ while thirteen (43\%) as NP.

Fifty-nine percent of $P$ cows reacted to 2 to 6 alien calves with an intensity of the reaction of 3 to 5 , while $46 \%$ of NP cows only reacted to one alien calf with a maximum intensity of 2 .

No difference was found between $P$ and NP cows in none of the reproductive characteristics evaluated (Table 1). Cows with no follicular presence reacted to a greater number of calves ( $\mathrm{R}=-.39 ; P=0.03)$ and cows displaying the higher intensity of reaction toward their calves were those that did not display estrous behavior ( $\mathrm{R}=-0.46 ; P=0.01$; Table 2$)$.

Table 1 Comparison of some reproductive variables between Protective and Non protective zebu cows at 25 days after parturition, following estrous induction with a progestogen implant at day 16 postpartum.

\begin{tabular}{|c|c|c|c|}
\hline Reproductive variables & Protective & No protective & $P$-value \\
\hline & \multicolumn{2}{|c|}{ Frequency / total number of cows (\%) } & \\
\hline Estrus display & $10 / 17(59)$ & $10 / 13(77)$ & 0.29 \\
\hline Ovulation & $13 / 17(76)$ & $11 / 13(84)$ & 0.58 \\
\hline \multirow[t]{2}{*}{ Follicular presence } & $4 / 17(24)$ & $5 / 13(38)$ & 0.37 \\
\hline & \multicolumn{2}{|c|}{ Mean $\pm \mathrm{EE}$} & \\
\hline Number of follicles* & $12.4 \pm 1.1$ & $12.6 \pm 1.7$ & 0.75 \\
\hline Estrus onset (h after implant withdrawal) & $52.90 \pm 2.1$ & $52.30 \pm 2.3$ & 0.74 \\
\hline Progesterone concentration at $35 \pm 1 \mathrm{~d}$ postpartum $(\mathrm{ng} / \mathrm{ml})^{*}$ & $3.31 \pm 0.57$ & $4.27 \pm 0.73$ & 0.44 \\
\hline
\end{tabular}

*The number of follicles corresponds to the sum of both ovaries.

The Chi square test was used to compare between columns using frequency values, while mean values were compared by $T$ test.

Cows were classified as protective $(\mathrm{P})$ when reacted towards $\geq 3$ calves, in intensities $\geq 3$; whilst non-protective cows (NP), did not react or reacted to $\leq 2$ calves with a reaction intensity $\leq 2$.

\section{Discussion}

In general, no difference in ovarian activity was found between protective and nonprotective cows. This could be due to at least three reasons: first, the arbitrary way that cows were classified within each category; second, the relatively small sample size; and third, consider all the 
components evaluated within the maternal protective behavior. While when segregating some of the components like the intensity of reaction toward their calf, had a significant effect on the display and onset of estrus.

The postpartum time of data collection could have affected the results; influencing the maternal protection behavior and reproductive response. About 99 to $100 \%$ of the suckling Bos taurus beef cows display maternal protective behavior reaction when approached by a vehicle (Flörcke et al 2012); or when their recently born calves are handled (Buddenberg et al 1986; Morris et al 1994). Similarly, in Bos indicus cattle at $25 \mathrm{dpp}, 90 \%$ of the cows protect their calves, and as days passed by, this percentage decrease to $40 \%$ at $120 \mathrm{dpp}$ (Pérez-Torres et al 2014). It is possible that since the calves in the present experiment were not manipulated, and were older than in previous studies, the response of the mothers could be diminished. On the other hand, the prompt reestablishment of the ovarian activity after parturition increases the possibilities of females getting pregnant as soon after calving (Chenoweth 1994); however, in zebu cattle, various factors influences postpartum ovarian reactivation (Díaz et al 2018), including the presence of the calf and the suckling stimulus (Short et al 1990; Mondragón et al 2016). Nevertheless, it has been demonstrated that a presynchronization program at day 25 could trigger the onset of ovarian activity and facilitate a breeding program (Baruselli et al 2004; Pérez-Torres et al 2015).

Table 2 Correlation values between reproductive variables and some protective maternal behavior components.

\begin{tabular}{lll}
\hline & $\begin{array}{l}\text { Number of calves the cow } \\
\text { reacted at }\end{array}$ & $\begin{array}{l}\text { Intensity of reaction to own } \\
\text { calf }\end{array}$ \\
\cline { 2 - 3 } $\begin{array}{l}\text { Estrus display (yes/no) } \\
\text { Ovulation (yes/no) }\end{array}$ & $-0.25(0.17)$ & $-0.46(0.01)^{* *}$ \\
Presence of follicles (yes/no) & $-0.26(0.15)$ & $-0.2(0.26)$ \\
Number of follicles & $-0.39(-0.03)$ & $0.11(0.52)$ \\
Estrus onset (h) & $0.07(0.69)$ & $0.11(0.52)$ \\
Progesterone concentration $(\mathrm{ng} / \mathrm{ml})$ at & $-0.09(0.65)$ & $-0.52(0.00)^{* * *}$ \\
$32 \mathrm{~d}$ postpartum & $-0.24(0.10)$ & $-0.1(0.19)$
\end{tabular}

Numbers in parentheses correspond to $P$-values. For dichotomous variables, a Point-biserial correlation test was used, while the Spearman correlation test was used to measure association with ordinal and continuous variables.

The results show that protective maternal behavior may have implications on ovarian activity and estrus display in postpartum zebu cows, which could be of use to improve reproductive strategies or postpartum synchronization programs by considering maternal characteristics as a possible factor associated with the success of these programs.

Our results could partly explain why the sole presence of the calf affects the reproduction of beef cows, since the different intensity of the protective behavior of a cow for her calf as well as the number of calves to which she reacts, could affect differently reproductive variable.

Further studies are needed involving a greater number of animals and segregate different components of the maternal behavior, to have a greater spectrum of association with the different reproductive variables. As the components of the behaviors are disaggregated, the possibilities of finding some effects seem to be enabled. Conversely, associations between temperament and reproductive traits in cows are poorly studied but appear to be weak and variable (Haskell et al 2014). No significant correlations were found between the Simmental cows' temperament and reproduction traits such as days open (0.01), number of inseminations per gestation (0.01), and the calving interval (0.08) (Haile-Mariam et al
2004; Sewalem et al 2011; Cziszter et al 2016). Other areas of research involve the study of hormones related to maternal behavior and reproduction, such as oxytocin, and steroids, as well as changes in the postpartum time of these relationships.

In conclusion, no difference in ovarian activity was found between protective and nonprotective cows. However, current results suggest that protective maternal components might affect some reproductive variables.

\section{Conflict of Interest}

The authors declare that they have no conflict of interest.

\section{Funding}

Authors are grateful for partial support received from Programa de Apoyo a Proyectos de Investigación e Investigación Tecnológica (PAPIIT) IN216820, Universidad Nacional Autónoma de México (UNAM).

\section{References}

Baruselli PS, Reis EL, Marques MO, Nasser LF, Bó GA (2004) The use of hormonal treatments to improve reproductive performance of anestrous beef cattle in tropical climates. Animal Reproduction Science 82:479-486.

Buddenberg BJ, Brown CJ, Johnson ZB, Honea RS (1986) Maternal behavior of beef cows at parturition. Journal of Animal Science 62:42-46. 
Chenoweth P (1994) Aspects of reproduction in female Bos indicus cattle: a review. Australian Veterinary Journal 71:422-426.

Cooke RF, Arthington JD, Araujo DB, Lamb GC (2009) Effects of acclimation to human interaction on performance, temperament, physiological responses, and pregnancy rates of Brahman-crossbred cattle. Journal of Animal Science 87:4125-4132.

Cooke RF, Schubach KM, Marques RS, Peres RF, Silva LG, Carvalho RS, Cipriano RS, Bohnert DW, Pires AV, Vasconcelos JL (2017) Effects of temperament on physiological, productive, and reproductive responses in beef cows. Journal of Animal Science 95:1-8.

Cziszter LT, Gavojdian D, Neamt R, Neciu F, Kusza S, Ilie DE (2016) Effects of temperament on production and reproductive performances in Simmental dual-purpose cows. Journal of Veterinary Behavior 15:50-55.

Díaz R, Galina CS, Rubio I, Corro M, Pablos JL, Orihuela A (2018) Monitoring changes in back fat thickness and its effect on the restoration of ovarian activity and fertility in Bos indicus cows. Reproduction of Domestic Animals 53:495-501.

Flörcke C, Engle TE, Grandin T, Deesing MJ (2012) Individual differences in calf defense patterns in Red angus bed cows. Applied Animal Behaviour Science 139:203-208.

Haile-Mariam M, Bowman PJ, Goddard ME (2004) Genetic parameters of fertility traits and their correlation with production, type, workability, live weight, survival index, and cell count. Australian Journal of Agricultural Research 55:77-87.

Haskell MJ, Simm G, Turner SP (2014) Genetic selection for temperament traits in dairy and beef cattle. Frontiers in Genetics 5:368.

Kasimanickam R, Asay M, Schroeder S, Kasimanickam V, Gay JM, Kastelic JP, Hall JB, Whittier WD (2014) Calm Temperament Improves Reproductive Performance of Beef Cows. Reproduction in Domestic Animals 49:10631067.
Mondragón V, Galina CS, Rubio I, Corro M, Salmerón F (2016) Effect of restricted suckling on the onset of follicular dynamics and body condition score in Brahman cattle raised under tropical conditions. Animal Reproduction Science 167:89-95.

Morris CA, Cullen NG, Kilgour R, Bremner KJ (1994) Some genetic factors affecting temperament in Bos taurus cattle. New Zealand Journal of Agricultural Research 37:167-175.

Orihuela A, Pérez-Torres L, Ungerfeld R (2020) The time relative to parturition does not affect the behavioral or aggressive reactions in zebu cows (Bos indicus). Livestock Science 234:103978.

Pérez-Torres L, Orihuela A, Corro M, Rubio I, Cohen A, Galina CS (2014) Maternal protective behavior of zebu type cattle (Bos indicus) and its association with temperament. Journal of Animal Science 92:4694-4700.

Pérez-Torres L, Rubio I, Corro M, Cohen A, Orihuela A, Galina CS, Pablos JL (2015) A pre-synchronization program at early postpartum might increase the chances of Bos indicus cows cycling prior to 50 days regardless of the length of calf separation. Journal of Reproduction and Development 61:199203.

Sewalem A, Miglior F, Kisteman GJ (2011) Genetic parameters of milking temperament and milking speed in Canadian Holsteins. Journal of Dairy Science 94:512-516.

Short RE, Bellows RA, Staigmiller RB, Berardinelli JG, Custer E (1990) Physiological mechanisms controlling anestrus and infertility in postpartum beef cattle. Journal of Animal Science 68:799-816. 